\title{
Petrogenesis of the Niagara Icefalls Ultramafic-mafic complex, Northern Victoria Land, Antarctica
}

\author{
A.T. $\operatorname{Arias}^{1 *}$, J.-W. Park ${ }^{1}$, S.-B. Yi², M.J. Lee ${ }^{2}$
}

${ }^{1}$ School of Earth and Environmental Sciences, Seoul National University, Seoul 08826, Republic of Korea

${ }^{2}$ Division of Polar Earth-System Sciences, Korea Polar Research Institute, Incheon 21990, Republic of Korea

The Niagara Icefalls ultramafic-mafic complex is located within the Wilson terrane, near to the tectonic border between the Bowers and Wilson terranes, within Northern Victoria Land, Antarctica. Previous studies indicate this complex was emplaced $\sim 514$ Ma during a period of extension within Northern Victoria Land, $[1,2]$ based on U-Pb zircon ages and the complex's boninite-like affinity [1].

In this study, we revisited the petrogenetic model of the Niagara Icefalls ultramafic-mafic complex using whole-rock and mineral major and trace elements from a more extensive sample set. Also, new zircon U-Pb SHRIMP analyses reveal a more complex petrogenetic model than previously described. The mineral and whole-rock data exhibit boninitic characteristics with very low whole-rock $\mathrm{TiO}_{2}$ content $(<0.07 \%)$ and depleted HREEs and HFSEs while showing a relative enrichment in LREEs and fluid-mobile elements. However, differences in mineral chemistry between wehrlites in the North, and a sequence of dunite, orthopyroxenite, and gabbronorite in the South, suggest these rocks were produced from different parental melts. Furthermore, zircons associated with pegmatitic gabbronorites, which cross-cut wehrlites, have a mean age of $513.7+/-2.6 \mathrm{Ma}$, whereas the mean age of zircons in gabbronorite associated with dunite and orthopyroxenite is $500.3+/-4.2 \mathrm{Ma}$. These temporal and chemical disparities among similar boninite-like plutonic rocks suggest they were formed at two stages. Firstly, 514 $\mathrm{Ma}$ an extensional event led to the melting of the refractory mantle wedge, forming a boninite-like melt. Subsequently, $\sim 500 \mathrm{Ma}$ the second instant of boninitic magmatism occurred, likely associated with the subduction of the Bowers back-arc. The higher degree of depletion in rocks associated with the $\sim 500$ Ma gabbronorite compared to those of the $\sim 514 \mathrm{Ma}$ pegmatitic gabbronorite may suggest the progressive depletion of the mantle wedge beneath the Wilson Terrane during the Ross Orogeny.

[1] Tribuzio et al. (2008) Contrib. Mineral. Petrol. 155, 619633. [2] Rocchi et al. (2011) Gondwana Res. 19, 594-607. 